\title{
COMPARISON OF ELECTROMAGNETIC AND SEISMIG-GRAVITY ICE THICKNESS MEASUREMENTS IN EAST ANTARCTICA
}

\author{
By David J. Drewry \\ (Scott Polar Research Institute, Cambridge CB2 IER, England)
}

\begin{abstract}
The errors involved in ice thickness determinations in Antarctica by seismic reflection shooting, gravity observations and radio-echo sounding are briefly discussed. Relative accuracies of $3 \%$, $7-10 \%$ and $1.5 \%$ have been suggested. Double checks of ice depths from radar sounding in east Antarctica indicate an internal consistency of measurement for this technique of $<\mathrm{r} \%$. Comparison of carefully executed seismic shooting and routine radio-echo sounding results against absolute ice thickness values from two deep core drilling sites show no significant differences between these two remote methods (i.e. both are better than $1.5 \%$ ).

Over 60 comparisons are examined between radar ice thicknesses and over-snow measurements obtained on eight independent traverses in east Antarctica. Three traverses exhibit consistently unacceptable resultsU.S. Victoria Land Traverse II (southern leg), Commonwealth Transantarctic Expedition and the U.S.S.R. Vostok to South Pole Traverse - which probably result from misinterpretation of "noisy" seismograms. The remaining comparisons indicate mean differences, including some navigational uncertainty, of $\approx 3 \%$, $<8 \%$ and $5 \%$ between radio-echo and (1) seismic, (2) gravity, and (3) gravity tied to seismic determinations, respectively.
\end{abstract}

RÉsumÉ. Comparaison des mesures d'épaisseur de glace, obtenue par methode électromagnétique et sismique/gravitéAntarctique Est. Dans cet article on analyse brièvement les erreurs consécutives à la détermination des épaisseurs de glace en Antarctique, par tir sismique, gravité ou par sondage radio-écho. Les précisions relatives de chaque méthode seraient de $3 \%, 7$ à $10 \%$ et $1,5 \%$. Plusieurs vérifications de mesure d'épaisseur par sondage radio, (Antarctique Est) montrent pour ces techniques, une cohérence de mesure, inférieure à $1 \%$. En effet, la comparaison entre les résultats obtenus par sondage radio-écho et sondage sismique d'une part, et d'autre part l'épaisseur de glace connue exactement par carottage, ne montre pas de différence significative entre ces deux méthodes de mesures à distance (toutes deux ont une précision meilleure que $1,5 \%$ ).

On a examiné plus de 60 comparaisons entre les épaisseurs de glace obtenues par radar et celles mesurées de pied ferme au cours de 8 expéditions indépendantes dans l'Est de l'Antarctique. Les résultats sur 3 expéditions sont manifestement inacceptables: branche sud U.S. Victoria Land Traverse II, Commonwealth Transantarctic Expedition, et Vostok - Pôle Sud (U.R.S.S.). Ceci provient sans doute d'un mauvais dépouillement des enregistrements de sismographes à fort "bruit de fond". Les autres comparaisons montrent de légères différences, provenant en partie des imprécisions d'itinéraire, inférieures respectivement à $\approx 3 \%,<8 \%$ et $5 \%$ entre sondage radio-écho et mesures (I) sismique, (2) gravitationnelles et (3) sismiquegravitationnelle combinées.

ZuSAMmenfassung. Vergleich zwischen elektromagnetischen und seismisch-gravimetrischen Eisdickenmessungen in der Ost-Antarktis. Es wird kurz auf die Fehler eingegangen, die bei Eisdickenmessungen in Antarktika mit Reflexions-Sprengseismik, mit Schwerebeobachtungen und mit Radar-Echolotungen auftreten. Relative Genauigkeiten von $3 \%, 7-10 \%$ und $1.5 \%$ scheinen erreichbar. Doppelmessungen der Eisdicke mit RadarLotungen in der Ost antarktis weisen eine innere Messgenauigkeit dieser Methode von $<1 \%$ aus. Der Vergleich von Ergebnissen der Sprengseismik und der Radar-Echolotung mit Absolutwerten der Eisdicke aus zwei Kerntief bohrungen ergibt keine signifikanten Unterschiede zwischen diesen beiden Fernmethoden (d.h. beide sind genauer als $1,5 \%$ ).

Die Untersuchung erstreckt sich auf über 6o Vergleiche zwischen Radar-Eisdicken und Oberflächenmessungen, die in acht unabhängigen Profilen in der Ost-Antarktis gewonnen wurden. Drei Profile weisen durchwegs unannehmbare Ergebnisse auf - nämlich der Südteil der US Victoria Land Traverse II, die Commonwealth Transantarctic Expedition und die UdSSR-Traverse von Vostok zum Südpol -, die vermutlich mit der Fehlinterpretation gestörter Seismogramme zu erklären sind. Die übrigen Vergleiche ergeben einschliesslich einer gewissen Navigationsunsicherheit mittlere Differenzen von weniger als $\approx 3 \%$, $<8 \%$ und $5 \%$ zwischen den Eisdicken aus Radar-Echolotungen bzw. denen aus (I) Sprengseismik, (2) Schweremessungen und (3) Schweremessungen in Verbindung mit Sprengseismik.

\section{INTRODUCTION}

Despite the proliferation of electromagnetic (radio-echo) sounding data for ice thickness from various polar regions, there have been few systematic comparisons between this method and conventional geophysical techniques. Much of the reported success for gravity determinations in Antarctica, for instance, may lie in the lack of suitable comparative data (Crary, 
I97I). This paper presents an analysis of over 6o comparisons of radio-echo measurements in east Antarctica with results of seismic-gravity observations conducted on eight over-snow traverses between $195^{8}$ and 1963 .

\section{Reliability OF GeOPHYSICAL DATA}

\section{i. Seismic shooting}

Normal errors encountered during seismic reflection exploration in polar regions have been discussed in detail by Robin (1958), Bentley (1964), and Robinson (unpublished).

A principal source of error in converting echo times to ice thickness arises from uncertainty of the propagation velocity of elastic waves $V_{\mathrm{p}}$ in ice due to vertical variations of density, temperature, crystal size and orientation within an ice mass. Strong anisotropy, for instance, significantly increases seismic velocities in ice (Röthlisberger, 1972) and has been found to be particularly widespread in west Antarctica (Bentley, 1971).

Refraction shooting is unable to determine changes in $V_{\mathbf{p}}$ at depth, as maximum values for $V_{\mathrm{p}}$ are encountered a few hundred metres below the ice surface. For this reason the accuracy of the recent velocity $\log$ of the Byrd bore-hole is particularly valuable. Bentley (1972) has shown that the average all-ice column velocity $V_{\mathrm{p}}=3.915 \mathrm{~km} \mathrm{~s}^{-1}$ is greater by $2.5 \%$ than that generally employed. It is uncertain, however, how typical this value is for the remainder of west or east Antarctica.

Bentley ( 1964 ) has suggested an accuracy of $3 \%$ for ice thickness values from seismic shooting in Antarctica. In view of the somewhat unknown physical variations within and approaching the bottom of an ice sheet, this appears to be a reasonable upper limit. Misinterpretation of seismograms (especially where surface "noise" may mask sub-glacial returns) may lead to gross errors in excess of this figure.

\section{ii. Gravity observations}

In contrast to seismic measurements which determine ice thickness at a point, gravity results yield only an average ice thickness giving rise to anomalies to a distance equivalent to the ice depth. Errors encountered by the technique have been discussed by Bentley (1964).

Uncertainty arises from instrumental drift and calibration, assumptions regarding the density of sub-glacial materials, and the use of empirically determined terrain correction factors. Imprecise knowledge of ice surface elevations is a major source of error in Antarctica leading to inaccuracies of the order of $\mathrm{I}_{5}$ to 20 mgal.

It is not uncommon, therefore, to encounter ice depth errors of between 15 and $20 \%$ in areas of irregular bedrock relief, poorly determined surface altitudes and rapidly changing sub-glacial rocks. An average accuracy for ice thickness measurements probably lies between 7 and $10 \%$ (Tsukernik, I962; Kapitsa and Sorokhtin, 1963).

\section{iii. Radio-echo sounding}

Errors deriving from system parameters have been discussed by Evans and Smith (1969) and Robin and others (1969). Choice of pulse length and overall bandwidth are most important as they give rise to a certain random uncertainty in timing the leading edge of weak echoes. The speed, scale, and sensitivity of the recording medium (e.g. photographic film) are also important for echo integration.

Error may be introduced into calculations of ice thickness by using uncertain values for the velocity of propagation of electromagnetic waves $V_{\mathrm{em}}$ in ice. A mean value for $V_{\mathrm{em}}$ of $169 \pm 2 \mathrm{~m} \mu \mathrm{s}^{-1}$ in pure polycrystalline ice has been suggested by Robin and others (1969) based on laboratory and field experiments. Other workers have undertaken field work to determine radio wave velocities including wide-angle reflection measurements (Jiracek, 
I967; Autenboer and Decleir, I969; Clough and Bentley, I970), comparison with seismic travel times (Clough and Bentley, 1970) and use of bore-hole data (Pearce and Walker, 1967).

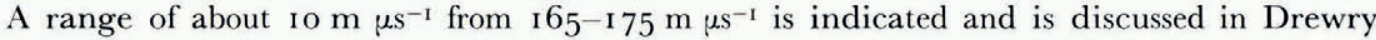
(unpublished). A $440 \mathrm{MHz}$ interferometric log of the $200 \mathrm{~m}$ bore hole on Devon Island has given a value at depth of $168.5 \mathrm{~m} \mu \mathrm{s}^{-1} \pm \mathrm{r} \%$ (Robin, 1975).

In general, $V_{\mathrm{em}}$ is affected by variations in snow or ice density and to a lesser extent by temperature (Bogorodsky and Fedorov, I967; Robin and others, I969; Clough and Bentley, 1970). Corrections can be made for faster travel times in the upper low-density accumulation zone of an ice mass. Such corrections become important on ice shelves where accumulation is large and thickness small. Under very cold conditions encountered in the high plateaux of East Antarctica the correction factor may reach $+16 \mathrm{~m}$ but is usually of the order of $4-8 \mathrm{~m}$ (Robin and others, I 969 ). In view of some uncertainties in the value of $V_{\mathrm{em}}$ and the smallness of the correction factor over the thick ice of east Antarctica, no corrections of this sort have been applied to the data presented here and a standard velocity of $\mathrm{I} 6 \mathrm{~g} \mathrm{~m} \mu \mathrm{s}^{-1}$ has been used throughout.

An analysis was made of the consistency and reliability of radio-echo results. Data from the $197 \mathrm{I}-72$ field season were chosen since the grid pattern of flight lines in East Antarctica ensured a large number of crossing points and accurate inertial navigation allowed positional errors to be minimized. Ninety-one locations were examined where ice thicknesses from two independent flights had been determined. Values for the crossing points gave a mean difference, without regard to sign, of $30.4 \mathrm{~m}$ and a standard deviation of $25.3 \mathrm{~m}$, equivalent to a mean percentage difference of $1.08 \%$. Since such estimates include some element of positional inaccuracy and operator error a value for the internal consistency of radio-echo measurements under field conditions of $<\mathrm{r} \%$ is suggested. Differences between separate observations of ice thickness are thus less than the errors of the radio-echo system itself, and show a level of replication consistent with their use as comparative data.

\section{iv. Navigational accuracy}

High positional accuracy is essential for comparison of non-synchronous ice depth measurements. Crary (1963), Robinson (unpublished) and Kapitsa (1960) have suggested a positional error usually better than $2-3 \mathrm{~km}$, for oversnow traverses based on astronomical and solar observations. Interpolated minor stations may have a relative error of up to $\mathrm{I} \mathrm{km}$. Airborne radio-echo navigation for measurements reported here was undertaken with two Litton LTN-5I Inertial Navigation Systems (INS) yielding in-flight errors of between o.o I and $0.4 \mathrm{~m} \mathrm{~s}^{-1}$. Flight line positions should, therefore, be accurate to $<5 \mathrm{~km}$ anywhere and between $2-3 \mathrm{~km}$ in most cases.

\section{v. Absolute checks of radio-echo and seismic results}

In two different locations there is opportunity to check the performance of both radio-echo and seismic sounding against absolute ice thickness measurements determined by deep core drilling to bedrock.

\section{(a) Camp Century, Greenland}

A core hole at Camp Century reached frozen till at a depth of $1387.4 \mathrm{~m}$ (Hansen and Langway, I966). Seismic soundings were made in the vicinity of Camp Century in I $_{96} 6$ by Alford (Mock, I965) and extrapolated to the hole ( $1382 \mathrm{~m}$ ). Over-snow radio-echo soundings were obtained within $300 \mathrm{~m}$ of the hole during 1964 (Robin and others, 1969) with a mean thickness of $\mathrm{I} 370 \mathrm{~m}$ (two-way delay of $\mathrm{I} 6 . \mathrm{I} \pm 0.2 \mu \mathrm{s}$ at a standard velocity of $V_{\mathrm{em}}=\mathrm{I} 69$ $\mathrm{m} \mu \mathrm{s}^{-1}$ plus a firn correction factor of $+8 \mathrm{~m}$ ). Pearce and Walker (1967) found a velocity of I $65 \mathrm{~m} \mathrm{\mu s}^{-1}$ from a comparison of a two-way travel time of $16.75 \mu \mathrm{s}$ with the bore-hole depth. 


\section{(b) New "Byrd" station, Antarctica}

During airborne radio-echo operations in $1967-68$ soundings were made around the 2 I64 $\mathrm{m}$ core hole at "Byrd" station and ice thicknesses of between 2104 and $2214 \mathrm{~m}$ were obtained (Robin and others, 1970). Examination of the original records by the author revealed weak, but distinguishable, continuous echoes at a distance of about $400 \pm 200 \mathrm{~m}$ from the hole, yielding a thickness of $2 \mathrm{I}_{50} \pm 30 \mathrm{~m}$ (Table I). Three seismic reflection shots were made near the core hole. Extrapolation gives a depth at the hole of 2 I $35 \pm 50 \mathrm{~m}$ (personal communication from C. R. Bentley).

Two bore-hole measurement comparisons indicate that there is little significant difference between the results of carefully executed seismic shooting and routine radio-echo sounding.

TABLE I. COMPARISON OF RADIO-ECHO AND SEISMIC ICE THICKNESSES WITH BORE-HOLE MEASUREMENTS

Camp Century

(N.W. Greenland)

(W. Antarctica)

\begin{tabular}{|c|c|c|c|}
\hline & $\begin{array}{c}\text { Bore-hole } \\
\text { depth } \\
\mathrm{m}\end{array}$ & $\begin{array}{c}\text { Radio-echo } \\
\text { depth } \\
\text { m }\end{array}$ & $\begin{array}{c}\text { Seismic } \\
\text { depth } \\
\mathrm{m}\end{array}$ \\
\hline \multirow[t]{2}{*}{$\begin{array}{c}\text { Camp Century } \\
\text { (N.W. Greenland) }\end{array}$} & $\begin{array}{l}\text { I } 370 \\
\text { (to silt) } \\
\text { I } 387 \\
\text { (to rock) }\end{array}$ & $\begin{array}{c}\text { 1 } 36 \text { I-1 } 379 \\
(\text { I } 370)\end{array}$ & 1 $3^{82}$ \\
\hline & $\begin{array}{c}\text { Difference } \\
\text { Percentage difference }\end{array}$ & $\begin{array}{l}-17 \\
1.2\end{array}$ & $\begin{array}{l}-5 \\
0.4\end{array}$ \\
\hline \multirow{2}{*}{$\begin{array}{c}\text { New "Byrd" station } \\
\text { (W. Antarctica) }\end{array}$} & 2164 & $2150 \pm 30$ & $2135 \pm 50$ \\
\hline & $\begin{array}{c}\text { Difference } \\
\text { Percentage difference }\end{array}$ & $\begin{array}{l}-14 \\
0.65\end{array}$ & $\begin{array}{l}-29 \\
\text { I. } 34\end{array}$ \\
\hline
\end{tabular}

\section{Radio-echo comparisons in east Antarctica}

Some limited comparisons of radio-echo and seismic-gravity measurements have been made in Antarctica (Fedorov, 1967; Jiracek, 1967; Robin and others, r970; Clough and Bentley, I970; Drewry, I971; Schaefer, 1972; Evans and others, 1972). Few, however, have discussed more than a handful of checks and none have been considered from a wide variety of sources.

\section{i. The raw data}

Radio-echo records from the $197 \mathrm{I}-72$ field season were examined at those locations where flight lines intersected the routes of previous over-snow traverses. Ice thicknesses were taken from the nominal crossing points of over-snow traverses and radio-echo flights assuming for both methods an initial positional uncertainty of $3 \mathrm{~km}$. If the navigational error was $>3 \mathrm{~km}$, depths were taken and averaged over a distance commensurate with the positional error (see footnote, Table II). The maximum and minimum thicknesses on either side of the nominal crossing point were also noted and are plotted in Figure $\mathrm{I}$.

\section{ii. Comparisons}

The results of 60 comparisons with ice thicknesses from eight over-snow traverses are plotted in Figure I. Differences between techniques show a wide scatter. If we accept the figure of $\approx 3 \%$ for the general agreement of radio-echo sounding and seismic measurements (Robin, I97I) then less than one-third of all comparisons made here fall within this limit. Since all checks include a small component of navigational error, radio-echo values at these $\mathrm{I} 8$ or so sites can be taken as confirming the seismic-gravity results. A difference of $10 \%$ 


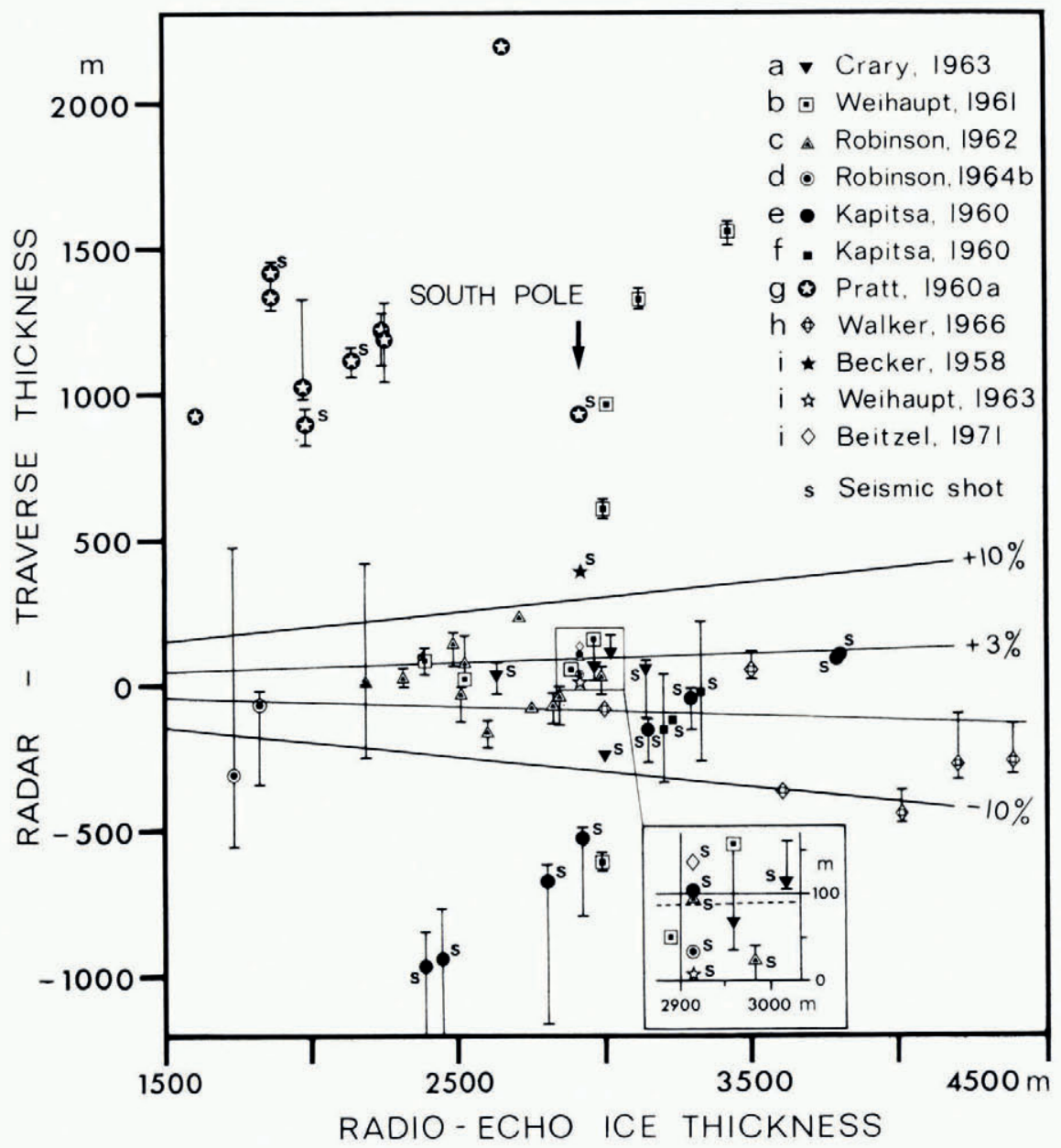

Fig. I. Comparison of seismic and gravity (principally tied to seismic) ice thickness measurements with S.P.R.I. radio-echo soundings in east Antarctica. Bars indicate range in thickness on either side of a traverse to a distance commensurate with the navigational error. Lower-case letters preceding key citations refer to discussion paragraphs in section $3(i i)$ of the text.

should allow for extreme positional errors. All values lying away from this line may be taken as significant deviations ( $2 \mathrm{I}$ in number) and those within but close to the $10 \%$ line as suspect.

In addition for each traverse a "traverse comparison" of a number of ice depth checks was made and is expressed throughout the text in the form:

$$
\left\{\frac{\sum(X-Y)}{n}\right\} \pm \sigma
$$

where $X$ is a radio-echo ice thickness, $Y$ is a traverse ice thickness (seismic or gravity), $n$ the total number of comparisons, and $\sigma$ the standard deviation about the mean difference.

(a) Victoria Land Traverse I, U.S.A., 1958-59 (Crary, 1963)

Details of equipment, logistics, and operations are reported in Crary (1963). Comparisons at five locations are given in Table II and Figure I. The agreements $(3-4 \%)$ are very good 
despite seismograms from four of these stations showing only "poor" reflections (Crary, r963). The mean difference without regard to sign is $99 \mathrm{~m}(3.3 \%)$.

TABle II. U.S.A. Victoria Land Traverse I

Over-snow traverse

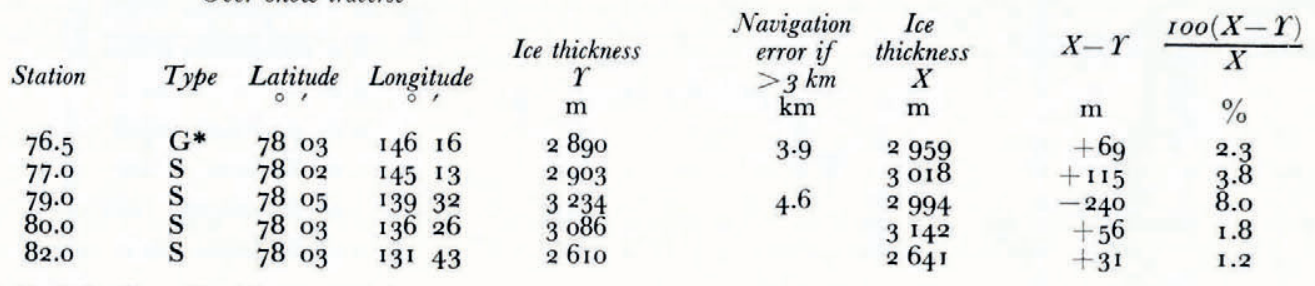

* Scaled off profile (Crary, 1963).
Radio-echo flights

Key to TABLES II TO IX

$\mathrm{G}=$ Gravity station; $\mathrm{S}=$ Seismic station; $Y=$ Traverse ice thickness; $X=$ Radio-echo ice thickness.

Radio-echo navigation error calculated as $\left[t C / T^{\prime}\right]+L$, where $t=$ time into flight, $C=$ flight closure error, $T^{\prime}=$ total flight duration, $L=$ an offset distance if no echoes at the crossing point.

(b) Victoria Land Traverse II, U.S.A., I959-6o (Weihaupt, I961)

Difficulties were encountered with strong surface noise on the southern leg of the traverse. Examination of the seismograms by A. P. Crary, C. R. Bentley, and E. S. Robinson revealed no reliable echoes. Gravity measurements were tied to the seismic results. Along this route radio-echo values diverge considerably from the traverse profile which gives a mean systematic underestimate of ice thickness by $900 \mathrm{~m}$ (Table III and Fig. I). The small difference between depths at $500 . \mathrm{B}$ is probably due to initial stations being tied to Crary's accurate station 72.o. The sub-glacial plateau, at $+500 \mathrm{~m}$ on Weihaupt's profiles, between stations $5^{\mathrm{I}} \mathrm{I}$ and $5^{26}$ is probably non-existent-it lies in an area shown by radio-echo mapping to be the northward extension of the Wilkes sub-glacial basin (Drewry, unpublished).

Table III. U.S.A. Victoria Land Traverse II

Over-snow traverse

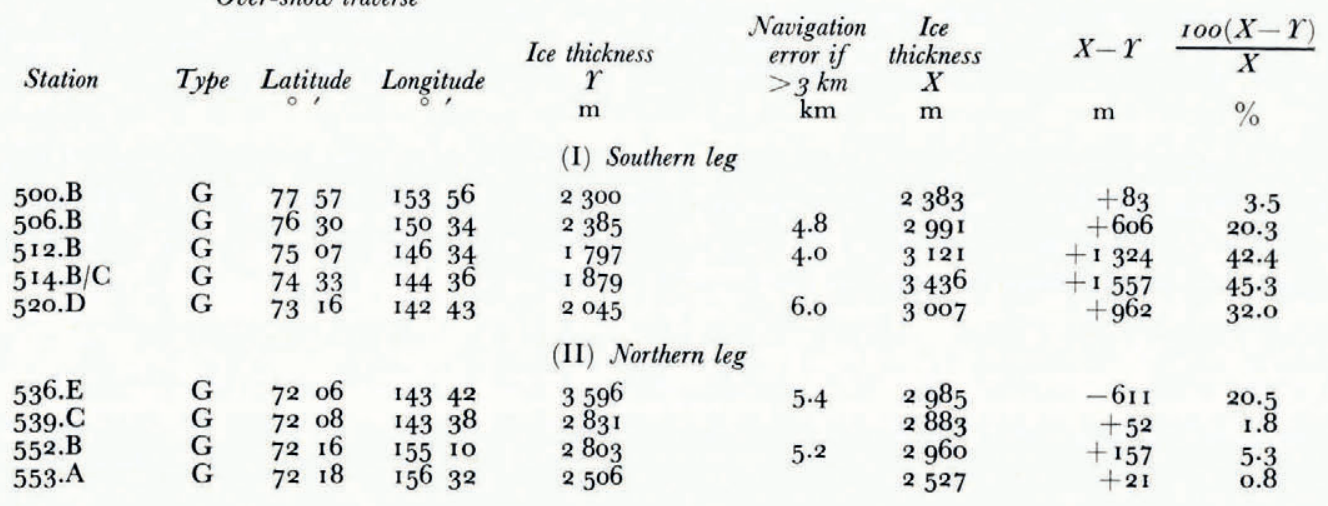

On the northern leg, seismograms show easily identifiable echoes, since higher firn temperatures experienced later in the season decreased surface noise. Four comparisons are available. Only at station 536 .E is there strong divergence. At this point Weihaupt (I96 I) 
records his greatest ice thickness $(3596 \mathrm{~m})$. The radio-echo record does not show echoes at the exact crossing point, but reflections $3 \pm 2.4 \mathrm{~km}$ away give a value of $2985 \mathrm{~m}$. Positional mismatch may be a part cause of the large difference noted. The remaining points show good agreement and confirm the northern leg to better than $4 \%$.

(c) McMurdo-South Pole Traverse, U.S.A., 1960-61 (Robinson, 1962; Crary, 1963)

Although none of the seismic stations was crossed by radio-echo flights, eleven intermediate seismic-tied gravity stations were checked (Table IV).

Table IV. U.S.A. McMurdo-South Pole Traverse

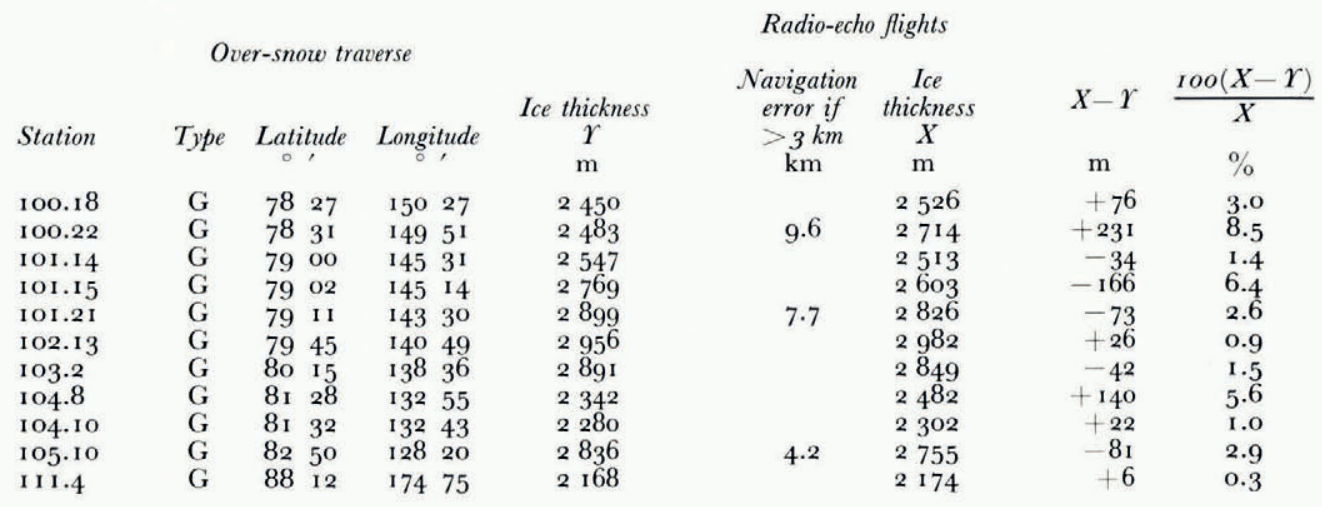

At only one station (IOI.I5) is the difference $>c .5 \%$. The radio-echo record here indicates a $50 \mathrm{~m}$ dip in the rock surface. Since elevations from gravity measurements are calculated from free-air anomalies by applying the Bouger correction for an infinite slab, the effects of any local topographic feature are minimized and in this case the bedrock dip has probably not been resolved. In general terms the relative sub-ice relief at all check points was small and agreement between gravity-tied-to-seismic and radio-echo depths is very close with an average difference, without regard to sign, of $63 \pm 53 \mathrm{~m}(2.4 \%)$.

\section{(d) South Pole Traverse, U.S.A., 1962-63 (Robinson, 1964)}

Only two of twelve radio-echo checks are considered to be representative due to uncertainties introduced by the large amplitude of relief, low navigational accuracy and small ice thickness (Drewry, unpublished). Both checks (Table V) are of gravity stations and differences reflect the presence of rugged sub-glacial terrain (see Fig. I). The radio-echo profiles from this region are preferred since the continuous record of ice thickness indicates the true roughness of the bed rather than the smoothed estimates of corrected free-air anomalies.

Table V. U.S.A. South Pole Traverse

\begin{tabular}{|c|c|c|c|c|c|c|c|c|}
\hline \multirow{4}{*}{ Station } & \multirow{2}{*}{\multicolumn{3}{|c|}{ Over-snow traverse }} & \multicolumn{4}{|c|}{ Radio-echo flights } & \multirow{3}{*}{$\frac{I O o(X-Y)}{X}$} \\
\hline & & & & & Navigation & & & \\
\hline & Type & Latitude & Longitude & $r$ & $>3 \mathrm{~km}$ & X & & \\
\hline & & 0 & , & $\mathrm{m}$ & $\mathrm{km}$ & $\mathrm{m}$ & $\mathrm{m}$ & $\%$ \\
\hline 117.6 & G & 8826 & $1544^{8 *}$ & 2050 & & I 74 I & -309 & 17.7 \\
\hline 117.11 & G & 8813 & 161 oo* & I 904 & & I 836 & -68 & 3.7 \\
\hline
\end{tabular}

* Longitude west of Greenwich. 
(e) Vostok-South Pole, U.S.S.R., 1959 (Kapitsa, r96o)

The route was crossed in seven places by radio-echo flights. Comparisons of ice depths indicates a number of large discrepancies up to $c$. I $000 \mathrm{~m}$ with a systematic overestimate of depths (Table VI, Fig. I). The profiles given by Kapitsa (I960) and reproduced in Atlas Antarktiki (Tolstikov, I966) suggest a relatively smooth "plain-like" character to the sub-ice surface. Continuous radio-echo sounding in the area indicates a very rough, mountainous topography for at least one third the distance between Vostok and the South Pole (Drewry, unpublished). There has been little doubt in the past of the validity of the seismic results of this traverse (Bentley, I964) although none of the seismograms has ever been released for examination. For this reason the comparisons are discussed below.

Table VI. U.S.S.R. Vostok-South Pole Traverse

\begin{tabular}{|c|c|c|c|c|c|c|c|c|}
\hline \multirow[b]{3}{*}{ Station } & \multirow{2}{*}{\multicolumn{3}{|c|}{ Over-snow traverse }} & \multicolumn{4}{|c|}{ Radio-echo flights } & \multirow{3}{*}{$\frac{\operatorname{Ioo}(X-r)}{X}$} \\
\hline & & & & & \multirow{2}{*}{$\begin{array}{c}\text { Navigation } \\
\text { error if } \\
>3 \mathrm{~km} \\
\mathrm{~km}\end{array}$} & \multirow{2}{*}{$\begin{array}{c}\text { Ice } \\
\text { thickness } \\
X \\
\mathrm{~m}\end{array}$} & \multirow[b]{2}{*}{$\begin{array}{c}X-r \\
\mathrm{~m}\end{array}$} & \\
\hline & Type & Latitude & Longitude & $\begin{array}{c}\text { Ice thickness } \\
r \\
\mathrm{~m}\end{array}$ & & & & \\
\hline Vostok & S & $\begin{array}{ll}78 & 28\end{array}$ & 10648 & 3700 & $4 \cdot 4$ & $3800^{\dagger}$ & +100 & 2.6 \\
\hline Vostok & $\mathrm{S}$ & $\begin{array}{ll}78 & 28\end{array}$ & I06 48 & 3700 & & $3802_{+}^{+}$ & $+\mathbf{1 0 2}$ & 2.7 \\
\hline Vostok & $\mathrm{S}$ & $\begin{array}{ll}78 & 28\end{array}$ & I06 48 & 3700 & & $3785 \S$ & $\begin{array}{r}+85 \\
\end{array}$ & 2.2 \\
\hline 3 & $\mathrm{~S}$ & 7927 & I 0643 & $335^{\circ}$ & & 3303 & -47 & 1.4 \\
\hline 6 & $\mathrm{~S}$ & $\begin{array}{lll}80 & 29\end{array}$ & 10652 & 3480 & & 2807 & -673 & 24.0 \\
\hline 7 & $\mathrm{~S}$ & 8052 & I06 50 & $345^{\circ}$ & & 2920 & -530 & 18.2 \\
\hline $8 / 9$ & $\mathrm{~S}^{*}$ & 8122 & ro6 $5^{\circ}$ & $335^{\circ}$ & & 2384 & -966 & $4^{0.5}$ \\
\hline 9 & $\mathrm{~S}$ & $\begin{array}{ll}81 & 42\end{array}$ & I06 55 & $33^{8} 7$ & & 2445 & $-94^{2}$ & 38.5 \\
\hline $16 / 17$ & S* & 8356 & Iо6 $5^{8}$ & 3305 & & 3152 & $\begin{array}{r}-153 \\
-\end{array}$ & 4.9 \\
\hline
\end{tabular}

The ice thickness as reported by Kapitsa (1960) from Vostok is $3700 \mathrm{~m}$. The difference between this and radio-echo measurements, made on three separate occasions and at two different frequencies, is only roo $\mathrm{m}(2.5 \%)$. Away from Vostok sub-glacial terrain is very rough with relative relief of $300-400 \mathrm{~m}$ and an autocorrelation distance (Drewry, unpublished) of $\approx 3.0 \mathrm{~km}$. At stations $6,7,8 / 9$, and 9 sub-ice topography is rugged and comprises part of a range of mountains (a portion of the Gamburtsev Mountains) lying across the traverse route. Differences between ice thicknesses are very large (especially in view of high navigational accuracy) being $673,530,966$, and $942 \mathrm{~m}$ respectively. In contrast at station $16 / 17$ terrain is relatively smooth (amplitude $<150 \mathrm{~m}$ ) and the radio-echo and seismic comparison is $5 \%(\mathrm{I} 53 \mathrm{~m})$.

In view of the consistency of radar results and continuous areal coverage in this region the mean differences of $502 \pm 366 \mathrm{~m}$ between the two techniques lead us to accept the radio-echo values. It is probable that disturbance of the seismic records by surface noise, similar to that reported by Crary (1963), has made the picking of sub-glacial reflections difficult and has introduced the large differences noted here.

(f) Mirny-Vostok, U.S.S.R., I959-6o (Kapitsa, I96o)

At Komsomolskaya, radio-echo depths are only available at a distance of $3.5 \pm 2.5 \mathrm{~km}$. A difference of $23 \mathrm{~m}$ from the station value was noted (Table VII). Since sub-glacial relief 
appears fairly smooth, the radio-echo value may be taken as confirming the seismic ice thickness. The other checked location lies approximately half-way between Komsomolskaya and Vostok. The ice thickness was calculated from the published profile in Atlas Antarktiki (Tolstikov, I 966 ) and includes operator error of $\pm 25 \mathrm{~m}$. Agreement is better than $5 \%$.

TABLE VII. U.S.S.R. Mirny-Vostok Traverse

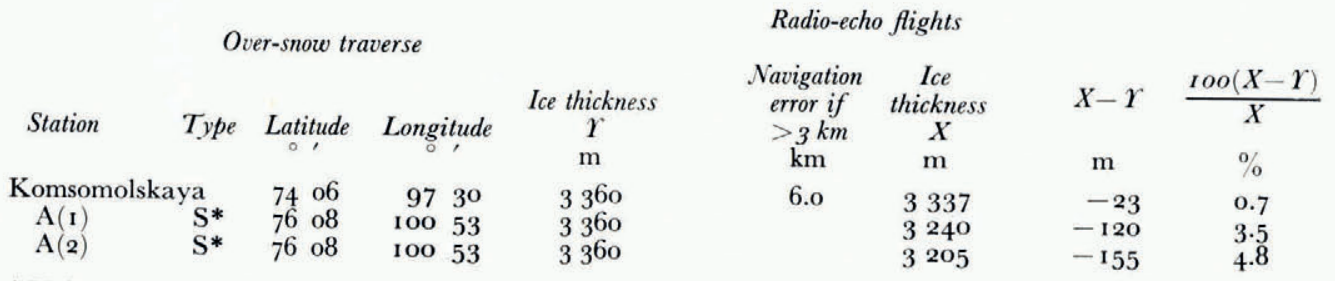

* Values scaled off published profile (Tolstikov, r966).

\section{(g) Commonwealth Transantarctic Expedition, 1957-58 (Pratt, i96o[a], [b])}

The seismic ice thicknesses reported by Pratt (196o[b]) have been critically reviewed by Robin (r962) and Bentley (r964). Due to shallow shot holes ( $<\mathrm{r} 2 \mathrm{~m})$ and lack of highfrequency recording equipment, seismograms show substantial disturbance from surface noise. Bentley (1964) and Robinson (unpublished) found no identifiable reflected events from bedrock. Pratt's gravity values also diverge widely from his seismic results. Woollard (I962) has recomputed the traverse profile using the free-air gravity anomalies tied to the South Pole

The original seismic data are referred to in this comparison (Table VIII, Fig. I). Pratt's values indicate substantially thinner ice between South Pole and Skelton Glacier than found from radio-echo sounding. An average difference of $\mathrm{I} 255 \pm 393 \mathrm{~m}$ was found from the points investigated - of the same order as Woollard's figure ( 1 ooo m) based on comparison with recalculated gravity values.

Table VIII. Commonwealth Transantarctic Expedition

\begin{tabular}{|c|c|c|c|c|c|c|c|c|}
\hline \multirow[b]{2}{*}{ Station } & \multicolumn{3}{|c|}{ Over-snow traverse } & \multicolumn{4}{|c|}{ Radio-echo flights } & \multirow[b]{2}{*}{$\frac{\operatorname{Ioo}(X-Y)}{X}$} \\
\hline & Type & Latitude & Longitude & $\begin{array}{c}\text { Ice thickness } \\
Y \\
\mathrm{~m}\end{array}$ & $\begin{array}{c}\text { Navigation } \\
\text { error if } \\
>3 \mathrm{~km} \\
\mathrm{~km}\end{array}$ & $\begin{array}{c}\text { Ice } \\
\text { thickness } \\
X \\
\mathrm{~m}\end{array}$ & $\begin{array}{c}X-r \\
\mathrm{~m}\end{array}$ & \\
\hline 109 & $\mathrm{~S}$ & $84 \quad 18$ & 13907 & I 090 & & I 985 & +895 & 45.0 \\
\hline I 13 & $\mathrm{G}$ & $834^{\circ}$ & I 4043 & 473 & & 2669 & +2 Ig6 & 82.5 \\
\hline 122 & S & $83 \circ 9$ & 14404 & 460 & & I 875 & +1415 & $75 \cdot 5$ \\
\hline $\begin{array}{l}125 \\
130 / 1\end{array}$ & $\begin{array}{l}\mathrm{G} \\
\mathrm{G}^{*}\end{array}$ & $\begin{array}{ll}82 & 49 \\
82 & \text { oo }\end{array}$ & $\begin{array}{l}14603 \\
14607\end{array}$ & 542 & & I 875 & + I 333 & 71.1 \\
\hline $140 / 1$ & $\mathrm{G}^{*}$ & $\begin{array}{ll}82 & 00 \\
80 & 37\end{array}$ & $\begin{array}{l}\text { I } 4607 \\
\text { I } 4531\end{array}$ & $\begin{array}{r}681 \\
\text { I OI } 5\end{array}$ & 4.0 & I 605 & +924 & $57 \cdot 5$ \\
\hline 142 & $\mathrm{G}$ & $\begin{array}{lll}80 & 26\end{array}$ & $\begin{array}{l}\text { I } 453^{1} \\
\text { I } 453^{8}\end{array}$ & $\begin{array}{ll}1 & 015 \\
1 & 061\end{array}$ & & $\begin{array}{ll}2 & 234 \\
2 & 244\end{array}$ & $\begin{array}{r}+1219 \\
+1183\end{array}$ & $\begin{array}{l}54.6 \\
52.7\end{array}$ \\
\hline 146 & $\mathrm{~S}$ & $795^{1}$ & 14800 & 1020 & & 2135 & $\begin{array}{r}113 \\
+115\end{array}$ & $\begin{array}{l}5^{2.1} \\
5^{2.2}\end{array}$ \\
\hline${ }^{1} 51 / 2$ & $\mathrm{G}$ & 7921 & I 50 I 3 & 946 & 3.2 & I 973 & +1027 & 52.0 \\
\hline
\end{tabular}

(h) Wilkes-Vostok Traverse, Australia, $1962-63$ (Walker, [1966])

An account of six comparisons along this traverse has been given in Evans and others (1972). Walker ([1966]) states that seismic reflections beyond $480 \mathrm{~km}$ from the coast were of poor quality with low signal-to-noise ratios. All the checks considered here, therefore, come from an essentially gravity profile tied to end points at Vostok and station V277. 
Table IX. Australian Wilkes-Vostok Traverse

Over-snow traverse

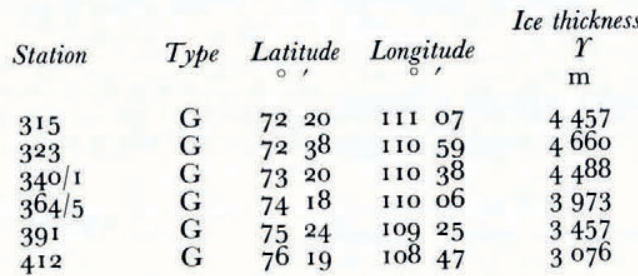

Radio-echo flights

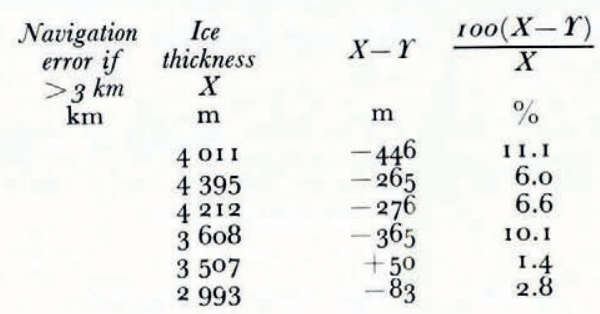

Agreement (Table IX) is on average 6.3\% (without regard to sign) which is within the normally expected accuracy of the technique. The very thick ice in the region, however, makes such percentage differences amount to between 100 and $500 \mathrm{~m}$, which are not inconsiderable. A systematic overestimate by gravity of ice depths of $230 \mathrm{~m}$ is indicated. The maximum thickness recorded by the Australian traverse $(4837 \mathrm{~m}$ ) at station $323.2 \mathrm{IB}$ (not tabulated) is within $3 \mathrm{~km}$ of a radio-echo flight line. It is clear from the radar records that sub-ice terrain is smooth, and continuous reflections show no ice thicker than $445^{\circ} \mathrm{m}$ in this area.

\section{(i) South Pole}

It is of interest to compare radio-echo soundings with a number of seismic investigations made at the South Pole (Table X). The quality of some of the latter have been reviewed by Bentley (1964).

Table X. South Pole Measurements

\begin{tabular}{|c|c|c|c|c|c|c|}
\hline $\begin{array}{l}\text { Electromagnetic } \\
\text { source and year of soundings }\end{array}$ & Time & $\begin{array}{c}\text { Tx delay } \\
\mu \mathrm{s}\end{array}$ & $\begin{array}{c}\text { Ice thickness } \\
\mathrm{m}\end{array}$ & $\begin{array}{c}\text { Mean delay } \\
\text { us }\end{array}$ & $\begin{array}{c}\text { Mean thickness } \\
X \\
\mathrm{~m}\end{array}$ & $\begin{array}{l}\text { Wave velocity } \\
\mathrm{m} \mu \mathrm{s}^{-1}\end{array}$ \\
\hline S.P.R.I., I97 I & $\begin{array}{l}053^{\circ} \\
053^{0.5} \\
053^{1} \\
053^{1} \cdot 5 \\
053^{2}\end{array}$ & $\begin{array}{l}34 \cdot 4^{1} 4 \\
34.568 \\
34 \cdot 533 \\
34.095 \\
34.462\end{array}$ & $\begin{array}{ll}2 & 908 \\
2 & 921 \\
2 & 918^{*} \\
2 & 88 \\
2 & 912\end{array}$ & $\begin{array}{l}34.494 \\
33.000\end{array}$ & $\begin{array}{l}2915 \pm 40 \\
2800 \pm 20\end{array}$ & $\begin{array}{c}169.0 \\
168.6-170.7\end{array}$ \\
\hline $\begin{array}{c}\text { Seismic } \\
\text { source and year of soundings }\end{array}$ & $\begin{array}{l}\text { Reflection time } \\
\mathrm{s}\end{array}$ & $\begin{array}{c}\text { Ice thickness } \\
Y \\
\mathrm{~m}\end{array}$ & $\begin{array}{l}\text { P velocity } \\
\mathrm{km} \mathrm{s}^{-1}\end{array}$ & $\begin{array}{l}\text { Distance } \\
\text { from Pole } \\
\mathrm{km}\end{array}$ & $\begin{array}{c}X-r \\
\mathrm{~m}\end{array}$ & 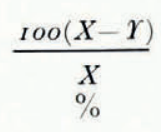 \\
\hline $\begin{array}{l}\text { Linehan, } 1957 \\
\text { Pratt, I } 958 \\
\text { Robinson and Thiel, } 1959 \\
\text { Kapitsa, } 1960 \\
\text { Weihaupt, } 1961 \\
\text { Robinson, I961 } \\
\text { Beitzel, I964 }\end{array}$ & $\begin{array}{l}1.400 \\
1.013 \\
1.508 \\
1.468 \\
1.55^{2} \\
1.467 \\
?\end{array}$ & $\begin{array}{ll}2 & 529 \\
1 & 990 \\
2 & 880 \\
2 & 810 \\
2 & 906 \\
2 & 820 \\
2 & 778\end{array}$ & $\begin{array}{c}3.810 \\
3 \cdot 936 \\
? \\
? \\
3 \cdot 9^{25} \\
3.850 \\
3 \cdot 770\end{array}$ & $\begin{array}{c}0.5 \\
0.5 \\
5 \cdot 5 \\
2.5 \\
0.5 \\
? \\
?\end{array}$ & $\begin{array}{r}+386 \\
+925 \\
+35 \\
+105 \\
+9 \\
+95 \\
+137\end{array}$ & $\begin{array}{r}13.2 \\
31.7 \\
1.2 \\
3.6 \\
0.3 \\
3.3 \\
4 \cdot 7\end{array}$ \\
\hline
\end{tabular}

* Not included in average ice thickness due to some disturbance on radio-echo record.

Seismograms from the earliest investigations of Linehan (Becker, I958) and Pratt ( 1960[a]) are badly disturbed by prolonged surface noise. The events identified on these records are probably not true bedrock reflections. 
Kapitsa and Sorokhtin (1963) have published seismograms made during r 960 in a $40 \mathrm{~m}$ hole $2.5 \mathrm{~km}$ from the South Pole. Reflections appear distinct and give a depth to bedrock of $2810 \mathrm{~m}$. The ice thickness of Robinson and Thiel $(2880 \mathrm{~m}), 5.5 \mathrm{~km}$ from the Pole, has been reported by Robinson (unpublished) who listed a further measurement from the McMurdo to South Pole Traverse of $2800 \mathrm{~m}$. The values given by Weihaupt (1963) were obtained in a $30-33 \mathrm{~m}$ deep hole at Amundsen-Scott Station. A depth of $2906 \mathrm{~m}$ was calculated using a velocity of $V_{\mathrm{p}}=3.925 \mathrm{~km} \mathrm{~s}^{-1}$ and a near-surface, low-velocity layer correction. A more recent determination at the South Pole was made during the Queen Maud Land Traverse leg I in 1964 by Beitzel (197I) yielding a value of $2778 \mathrm{~m}$. In I964 Jiracek undertook experimental electromagnetic soundings in Antarctica including measurements at the South Pole (Jiracek, I967). A spread of thicknesses were derived using velocities $\mathrm{r} 68.6 \leqslant V_{\mathrm{em}} \leqslant \mathrm{I} 70.7 \mathrm{~m} \mathrm{~s}^{-1}$ yielding a mean value of $2800 \pm 20 \mathrm{~m}$ (Jiracek and Bentley, I97 I).

The S.P.R.I. radio-echo measurements were made along the skiway at Amundsen-Scott Station and are of the order of $75 \mathrm{~m}$ greater than most of the seismic results. The adjacent reflection shots of Weihaupt are in close agreement, whilst the results of Robinson and Thiel (some $5 \mathrm{~km}$ distant) fall within the envelope of values (Table $\mathrm{X}$ ). The difference between some seismic and radio-echo results probably originates from uncertainty in seismic velocity and firn correction factors or from positional differences. An ice thickness of $29^{1} 5 \mathrm{~m}$ is suggested for the South Pole (Fig. 2).

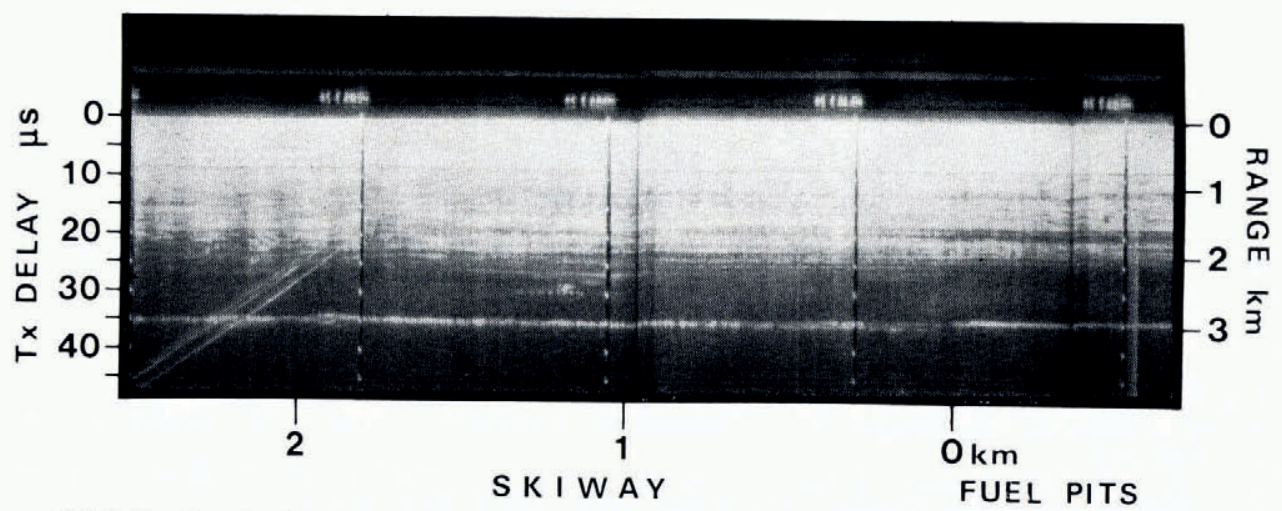

Fig. 2. S.P.R.I. radio-echo film record of ice thickness at South Pole. Intermediate layers indicated. Slanting echoes generated by surface artifacts.

\section{Conclusions}

Radio-echo determinations of ice thickness in east Antarctica indicate that three traverses or parts of traverses consistently exhibit substantial differences-U.S. Victoria Land Traverse II, southern leg (29\% mean difference), Commonwealth Transantarctic Expedition $(60 \%)$ and U.S.S.R. Vostok to South Pole Traverse (19\%). Such extreme values have probably resulted from misidentification of reflections on "noisy" seismograms. Ignoring such extremes, the mean difference in ice thickness from seismic shooting alone, without regard to sign, is $95 \pm 75 \mathrm{~m}$. This is a difference of $\approx 3 \%$. In view of navigational uncertainties it is close to the general $3 \%$ agreement between the two techniques suggested by Robin (I97I). No statistically significant systematic over- or under-estimate of ice thickness was apparent.

Gravity observations, mostly tied to seismic depths and excluding extreme values, show a mean difference without regard to sign of $120 \pm 176 \mathrm{~m}(4.1 \%)$. The ice thicknesses of the 
Wilkes to Vostok Traverse provide the only gravity data considered here more or less uncontrolled by seismic shooting. The mean difference is $248 \pm 155 \mathrm{~m}(6.3 \%)$, or $-230 \pm 183 \mathrm{~m}$ $(-5.9 \%)$ with regard to sign, suggesting for this traverse a systematic overestimate of ice depth by gravity observations. Extrapolation of this result to other gravity traverses is, however, uncertain.

In conclusion, two absolute checks of carefully executed seismic measurements and routine radio-echo soundings with bore-hole data show differences of $<\mathrm{r} .5 \%$. Average differences between radar depths and those of (i) seismic shooting, (ii) gravity observations and (iii) gravity values tied to seismic shots, including some navigational uncertainty, are better than $4 \%, 8 \%$, and $5 \%$ respectively. Gross errors of interpretation in seismic exploration, however, give rise to the more substantial differences noted between the techniques. It seems clear that radio-echo results, with a replication error of $<\mathrm{I} \%$ and continuous records facilitating ready checks of echo quality and continuity should be used as a standard reference for other geophysical measurements in polar ice sheets.

\section{Acknowledgements}

I am most grateful to Dr C. R. Bentley for providing unpublished material of seismic shooting at "Byrd" station. I am also indebted to an anonymous reviewer for suggesting useful modifications to the original draft. I wish to thank Dr G. de Q. Robin for many helpful discussions of the material presented in this paper and, as Director, for making available the facilities of the Scott Polar Research Institute.

\section{REFERENCES}

Autenboer, T. van, and Decleir, H. 1969. Airborne radio-glaciological investigations during the 1969 Belgian Antarctic expedition. Bulletin de la Société Belge de Géologie, de Paléontologie et d'Hydrologie, Tom. 78, Fasc. 2,

p. 87-100.
Becker, W. 1958. South Pole land above sea level. Proceedings of the United States Naval Institute, Vol. 84, No. 2, p. $144^{1-43}$.

Beitzel, J. E. 1971. Geophysical exploration in Queen Maud Land, Antarctica. (In Crary, A. P., ed. Antarctic snow and ice studies II. Washington, D.C., American Geophysical Union, p. 39-87. (Antarctic Research Series, Vol. 16.))

Bentley, C. R. 1964. The structure of Antarctica and its ice cover. (In Odishaw, H., ed. Research in geophysics. Vol. 2. Solid earth and interface phenomena. Cambridge, Mass., M.I.T. Press, p. $335^{-89 .)}$

Bentley, C. R. 1971. Seismic anisotropy in the west Antarctic ice sheet. (In Crary, A. P., ed. Antarctic snow and ice studies II. Washington, D.C., American Geophysical Union, p. 131-77. (Antarctic Research Series, Vol. 16.))

Bentley, C. R. 1972. Seismic-wave velocities in anisotropic ice: a comparison of measured and calculated values in and around the deep drill hole at Byrd station, Antarctica. Fournal of Geophysical Research, Vol. 77, No. 23,

p. 4406-20.
Bogorodskiy, V. V., and Fedorov, B. A. 1967 . Radiolokatsionnoye zondirovaniye lednikov [Radio echo sounding of glaciers]. Informatsionnyy Byulleten' Sovetskoy Antarkticheskoy Ekspeditsii, No. 65, p. 105-14.

Clough, J. W., and Bentley, C. R. 1970. Measurements of electromagnetic velocity in the east Antarctic ice sheet. [Union Géodésique et Géophysique Internationale. Association Internationale d'Hydrologie Scientifique.] [International Council of Scientific Unions. Scientific Committee on Antarctic Research. International Association of Scientific Hydrology. Commission of Snow and Ice.] International Symposium on Antarctic Glaciological Exploration (ISAGE), Hanover, New Hampshire, U.S.A., 3-7 September 1968, p. $115-28$.)

Crary, A. P. 1963. Results of United States traverses in east Antarctica, 1958-1961. I.G.Y. Glaciological Report (New York), No. 7 .

Crary, A. P. 1971. Thickness of ice and isostatic adjustments of ice-rock interface. (In Quam, L. O., ed. Research in the Antarctic. Washington, D.C., American Association for the Advancement of Science, p. 341-49.)

Drewry, D. J. I971. Subglacial morphology between the Transantarctic Mountains and the South Pole. (In Adie, R. J., ed. Antarctic geology and geophysics. Symposium on Antarctic geology and solid earth geophysics, Oslo, 6-15 August 1970. Oslo, Universitetsforlaget, p. 693-703.)

Drewry, D. J. Unpublished. Sub-ice relief and geology of east Antarctica. [Ph.D. thesis, University of Cambridge, 1973.$]$ 
Evans, S., and Smith, B. M. E. 1969. A radio echo equipment for depth sounding in polar ice sheets. Journal of Scientific Instruments (Journal of Physics, E), Ser, 2, Vol. 2, No. 2, p. 13 1-36.

Evans, S., and others. 1972. Radio-echo sounding in Antarctica, 1971-72, by S. Evans, D. J. Drewry and G. de Q. Robin. Polar Record, Vol. 16, No. I01, p. 207-12.

Fedorov, B. A. 1967. Primeneniye aktivnoi radiolokatsii dlya izucheniya antarkticheskikh [Use of active radio echo sounding in the study of Antarctic glaciers]. Informatsionnyy Byulleten' Sovetskoy Antarkticheskoy Ekspeditsii, No. 62 , p. $19^{-24}$

Hansen, B. L., and Langway, C. C., jr. 1966. Deep core drilling in ice and core analysis at Camp Century, Greenland, 1961-1966. Antarctic Journal of the United States, Vol. I, No. 5, p. 207-08.

Jiracek, G. R. 1967 . Radio sounding of Antarctic ice. University of Wisconsin. Geophysical and Polar Research Center. Research Report Series, No. 67-1.

Jiracek, G. R., and Bentley, C. R. 1971. Velocity of electromagnetic waves in Antarctic ice. (In Crary, A. P., ed. Antarctic snow and ice studies II. Washington, D.C., American Geophysical Union. p. 199-208. (Antarctic Research Series, Vol. i6.))

Kapitsa, A. P. I96o. Novyye dannyye o moshchnosti lednikovogo pokrova tsentral'nykh rayonov Antarktidy [New data on the thickness of the ice cover of the central regions of Antarctica]. Informatsionnyy Byulleten, Sovetskoy Antarkticheskoy Ekspeditsii, No. 19, p. 10-14.

Kapitsa, A. P., and Sorokhtin, O. G. I963. On errors in interpretation of reflection seismic shooting in the Antarctic. Union Géodésique et Géophysique Internationale. Association Internationale d'Hydrologie Scientifique. Assemblée générale de Berkeley, 19-3-3I-3 1963. Commission des Neiges et des Glaces, p. 162-64.

Mock, S. J. 1965. Glaciological studies in the vicinity of Camp Century, Greenland. U.S. Cold Regions Research and Engineering Laboratory. Research Report 157.

Pearce, D. C., and Walker, J. W. I967. An empirical determination of the relative dielectric constant of the Greenland ice cap. Journal of Geophysical Research, Vol. 72, No. 22, p. 5743-47.

Pratt, J. G. D. I960[a]. A gravity traverse of Antarctica. Transantarctic Expedition 1955-1958 Scientific Report No. 2.

Pratt, J. G. D. 1960[b]. Seismic soundings across Antarctica. Transantarctic Expedition 1955-1958 Scientific Report No. 3.

Robin, G. de Q. I958. Glaciology. III. Seismic shooting and related investigations. Norwegian-British-Swedish Antarctic Expedition, 1949-52. Scientific Results, Vol. 5 .

Robin, G. de Q. 1962. Trans-Antarctic Expedition, 1955-58. Scientific Reports Nos. 2 and 3 . Nature, Vol. 189 , No. 4767 , p. $781-82$

Robin, G. de Q. I971. Radio-echo sounding applied to the investigation of the ice thickness and sub-ice relief of Antarctica. (In Adie, R. J., ed. Antarctic geology and geophysics. Symposium on Antarctic geology and solid earth geophysics, Oslo, 6-15 August 1970. Oslo, Universitetsforlaget, p. 675-82.)

Robin, G. de Q. 1975. Velocity of radio waves in ice by means of a bore-hole interferometric technique. Journal of Glaciology, Vol. I 5 , No. 73 , p. I $_{5} \mathrm{I}-59$.

Robin, G. de Q., and others. 1969 . Interpretation of radio echo sounding in polar ice sheets, by G. de Q. Robin, S. Evans and J. T. Bailey. Philosophical Transactions of the Royal Society of London, Ser. A, Vol. 265, No. 1166, p. $437-505$.

Robin, G. de Q., and others. 1970. Radio echo exploration of the Antarctic ice sheet, by G. de Q. Robin, C. W. M. Swithinbank and B. M. E. Smith. [Union Géodésique et Géophisique Internationale. Association Internationale d'Hydrologie Scientifique.] [International Council of Scientific Unions. Scientific Committee on Antarctic Research. International Association of Scientific Hydrology. Commission of Snow and Ice.] International Symposium on Antarctic Glaciological Exploration (ISAGE), Hanover, New Hampshire, U.S.A., 3-7 September 1968, p. 97-115.

Robinson, E. S. 1962. Results of geophysical studies on the McMurdo-South Pole traverse. University of Wisconsin. Geophysical and Polar Research Center. Research Report Series, No. 62-6.

Robinson, E. S. 1964. Some aspects of sub-glacial geology and glacial mechanics between the South Pole and the Horlick Mountains. University of Wisconsin. Geophysical and Polar Research Center. Research Report Series, No. 64-7.

Robinson, E. S. Unpublished. Geological structure of the Transantarctic Mountains and adjacent ice covered areas. [Ph.D. thesis, University of Wisconsin, 1964.]

Röthlisberger, H. 1972. Seismic exploration in cold regions. U.S. Cold Regions Research and Engineering Laboratory. Cold regions science and engineering. Hanover, N.H., Pt. II, Sect. A2a.

Schaefer, T. G. 1972. Radio echo sounding in western Dronning Maud Land, 1971-a preview. South African Journal of Antarctic Research, No. 2, p. 53-56.

Tolstikov, Ye. I., ed. I966. Atlas Antarktiki [Atlas of the Antarctic]. Moscow, Leningrad, Glavnoye Upravleniye Geodezii i Kartografii.

Tsukernik, V. B. 1962. Novyye dannyye o podlednom rel'yefe tsentral'nogo sektora vostochnoy Antarktidy po seysmogravimetricheskim materialam [New data on subglacial relief in the central sector of eastern Antarctica from seismic and gravimetric materials]. Informatsionnyy Byulleten' Sovetskoy Antarkticheskoy Ekspeditsii, No. 32, p. 10-14.

Walker, D. J. [1966.] Geophysical surveys, Wilkes, Antarctica, 1962-63. Melbourne, Bureau of Mineral Resources, Dept. of National Development.

Weihaupt, D. J. 1963. Seismic and gravity studies at the South Pole. Geophysics, Vol. 28, No. 4, p. 582-92.

Weihaupt, J. G. 1961. Geophysical studies in Victoria Land, Antarctica. University of Wisconsin. Geophysical and Polar Research Center. Research Report Series, No. I.

Woollard, G. P. 1962. Crustal structure in Antarctica. (In Wexler, H., and others, ed. Antarctic research: the Matthew Fontaine Maury memorial symposium. [Edited by] H. Wexler, M. F. Rubin and J. E. Caskey, Jr. Washington, D.C., American Geophysical Union, p. 53-73. (Geophysical Monograph Series, No. 7.)) 


\section{DISGUSSION}

M. V. BERRY: Dr Robin pointed out in his paper yesterday that refraction affects radio and seismic waves differently; radio waves are made more, and seismic waves less, directional. Could this mean that the first seismic return might sometimes be a side echo, thus explaining gross differences in depth estimation?

D. J. Drewry: Such differences in refraction effects might lead to the occasional, nonsystematic divergence between seismic and radio depth determination if, for specular reflection, the sub-ice terrain is rough at a scale comparable with the beam width. Very large differences $(>500 \mathrm{~m})$, however, appear unlikely to be explained by this effect. In the case of extreme and persistent discrepancies reported here, the sub-ice terrain did not exhibit great roughness and the differences noted are probably real.

M. E. R. WALFORD: Is it possible to re-assess the seismograms taken by Pratt in the light of hindsight provided by radio-echo depths?

Drewry: When gravity observations are made in conjunction with seismic soundings, the gravity results can be used initially to locate those parts of seismograms where reflected events from bedrock should be expected. Pratt did not use his gravity measurements in this way. Subsequently Woollard recomputed the gravity observations which showed considerable differences with the seismic data. There would be little gained in re-interpreting Pratt's seismograms now, since they are badly disturbed by surface noise, and the area of the traverse has now been adequately covered by subsequent radio-echo sounding flights.

G. DE Q. Robin: Pratt identified two echoes at the South Pole station. One of the two is in agreement with the radio-echo sounding depth, but Pratt believed the other (earlier) echo to be the one from bedrock.

T. van Autenboer: Have you made comparisons between radio-echo ice depths and gravimetric ice thickness determinations - without seismic control-over narrow glaciers, such as those in the Transantarctic Mountains?

Drewry: No. We do have data close to a few of the gravity measurements on outlet glaciers in the Transantarctic Mountains. Because of low navigational accuracy on some of our flights, we have not yet interpreted the data sufficiently for a comparison.

J. W. Clough: If we use the radio-echo depth as a standard, then accepting that there may be different horizons near bedrock for reflecting the seismic and radio-echo pulse, we may attribute differences between the depths determined by radio-echo and seismic methods to differences in seismic velocity. Whereas there is considerable anisotropy in seismic velocity, it is negligible for electromagnetic waves, so the differences in depth provide us with information about the ice fabric. 